\title{
Rejuvenating Yamuna River by Wastewater Treatment and Management
}

\author{
Natarajan Pachamuthu Muthaiyah \\ Department of Centre for Climate Change, Periyar Maniammai University, Thanjavur, India \\ Email address: \\ natarajan_pm@yahoo.com
}

\section{To cite this article:}

Natarajan Pachamuthu Muthaiyah. Rejuvenating Yamuna River by Wastewater Treatment and Management. International Journal of Energy and Environmental Science. Vol. 5, No. 1, 2020, pp. 14-29. doi: 10.11648/j.ijees.20200501.13

Received: July 12, 2020; Accepted: November 13, 2020; Published: MM DD, 2020

\begin{abstract}
Yamuna is the most important tributary of Ganga River originating from the Yamunotri glacier of Himalaya, the 'Asian Water Tower'. Since Yamuna is fed by the above glacier, the Ganga River supplies water perennially. The catchment area of Yamuna River is 3, 45,848 $\mathrm{km}^{2}$ which is the largest among the other tributaries of Ganga. Surface water resource of the Yamuna River is $61.22 \mathrm{~km}^{3}$ and the net groundwater availability is $45.43 \mathrm{~km}^{3}$. Total sewage generation per annum from domestic and industrial sources in Yamuna River basin is about $9.63 \mathrm{~km}^{3}$. Due to the mixing of the above human influenced sewage, the waterways of this basin are stinking in many reaches and almost dead near Delhi. The pollution loads of the stinking and dead reaches of this river pollute the groundwater of the Yamuna River basin in many reaches. To treat and recycle the above sewage load about 1,320 sewage treatment plants are necessary. The capital and annual maintenance cost of these plants are Rs. 22, 440 million $/ \$ 320.57$ million, Rs. 10,070million $/ \$ 143.86$ million respectively (at one US dollar equal to Rs. 70). Benefits of the Yamuna River basin sewage treatment and recycling are 1. About 1,156.32million $\mathrm{m}^{3}$ of biogas can be produced per annum 2. Or from the biogas about 2,312.64million kwh electricity can be produced and the value of the electricity is Rs. 8,044.24million $/ \$ 144.92$ million 3. The biogas can be used for running the sewage treatment plants and for cooking directly through pipes 4 . About 433.62 million tons of bio-sludge can be obtained per annum and used of agriculture with suitable amendments 5 . About $45.43 \mathrm{~km}^{3}$ of groundwater of this basin can be protected from the sewage loads 6 . About $9.63 \mathrm{~km}^{3}$ of the treated sewage per annum can be used for nondomestic uses and this much quantity of fresh water can be conserved from this basin for future use 7 . The foul smell and the stinking environment of this basin can be completely stopped 8. The waterborne diseases and other water miseries will be arrested and 9. Above all the waterways can be made living rivers once again. The value of the $9.63 \mathrm{~km}^{3}$ of conserved freshwater per annum is Rs. $14,45,185.33$ million $/ \$ 20,645.50$ million. In the present scenario of water stress and scarcity in the 21 st century in many nations, using freshwater for all uses including for toilet is the outdated hypothesis.
\end{abstract}

Keywords: Yamuna River, Pollution Load, New Hypothesis, Wastewater Treatment and Management

\section{Introduction}

Domestic wastewater includes black water (fecal sewage) and gray water (wastewater from dishwashers, washing machines, sinks, and baths). Black water accounts for $32.5 \%$ of domestic wastewater, while gray water accounts for $67.5 \%$. Domestic wastewater is categorized as organic pollutants. The industrial polluted water has many types of harmful chemicals. Presently the domestic and the industrial wastewaters are polluting ground and surface waters, land, air, ecosystems and the entire environment. One of the main reasons for the dwindling freshwater resource in the hydrologic cycle in many countries is pollution of freshwater by the untreated or partially treated domestic and industrial sewages. Since the untreated sewage is deteriorating the freshwater resources of the physical and economic water scarcity regions already, if the wastewater is allowed without treatment in the water bodies and land, it will further pollute the meagre freshwater resources there, and increase the water scarcity many folds in these regions. Because sewage is mainly biodegradable and most of it is broken down in the environment, many rivers in the world are either biologically sick, dying or already dead.

The standing example of untreated sewage causing 
harmful algal blooms like the one that cost Toledo, Ohio, its drinking water in the 2015 summer, fish kills like the one recently reported in off Long Island, and the much-discussed dead zone in the Gulf of Mexico are all due to phosphorus, nitrogen, and other contaminants found in the untreated sewage that, according to EPA estimates, flows out of America's treatment plants during the 23,000 to 75,000 sanitary-sewer overflows that happen per year [1].

In USA, 3.5 million people get sick each year after swimming, boating, fishing, or otherwise touching water they thought was safe. This is because, human waste mingles with household chemicals, personal hygiene products, pharmaceuticals, and everything else that goes down the drains in American homes and businesses enter the river ultimately. Each year, more than 860 billion gallons of this unpleasant brew escapes sewer systems across the country. This is enough to flood all of Pennsylvania ankle-deep. It is enough for every American to take one bath each week for an entire year.

We must know that the untreated human sewage cause salmonella (a bacterium that occurs mainly in the intestine), hepatitis (a disease characterized by inflammation of the liver), dysentery, cryptosporidium, and many other infectious diseases [2].

In 1969 Ohio's Cuyahoga River was so fouled by industrial pollution that the river caught on fire. The public outcry over dirty rivers compelled Congress to pass the landmark Clean Water Act in 1972. The historic law was designed to protect all American waters, from the smallest streams to the mightiest rivers from pollution and destruction [3].

The Río Nuevo flows north from Mexico into the United States, passing through a gap in the border fence. This river is filled with sewage and toxic pollution.

The murky green water reeks of sewage and carries soapsuds, pieces of trash and a load of toxic chemicals from Mexicali, a city filled with factories that manufacture products from electronics to auto parts.

The water in this river is so polluted that people who cross it get itchy rashes or sores, and anyone who gets even a splash in the mouth becomes violently ill and people who live next to the river, the odor can be so overpowering that it gives them headaches. Their eyes water and their nasal passages sting. To escape the stench, residents avoid spending time outdoors in their yards [4].

The U.S. Environmental Protection Agency (EPA) stated in a 2018 report that $53 \%$ of river and stream miles, $71 \%$ of lake acres, $79 \%$ of estuarine square miles, and $98 \%$ of Great Lakes shoreline miles that have been assessed are classified as impaired (unacceptable for at least one designated use)" [5].

If this is the case in an advanced developed country like USA where there is a strict Clean Water Act 1972, what will happen in developing and least developed nations where there is open defecation and most of the raw sewage is often causes problems when people flush chemical and pharmaceutical substances down the toilet.
Presently, many rivers in the world have been polluted by human intervention, and it is indeed very unfortunate to note that many of them are on the verge of biologically dying. The ten rivers Mississippi River U.S.A, Sarno River Italy, Marilao River Philippines, Yellow River China, Jordan River Israel, River Yamun India, Buriganga River Bangladesh, Matanza-Riachuelo River Argentina, Ganges River India and Citarum River Indonesia are coming under the biologically polluted category. Not only these 10 rivers are biologically sick, but many rivers are biologically under threat due to the human influence [6].

Sucheta Pradhan also quoted the words of - John Kerry about the present status of American rivers as follows. "In $44 \%$ of all river bodies and streams, it is not safe to fish or swim. And yet industrial polluters continue to block legislation that would prevent mercury and Methyl tertbutyl ether (MTBE) from polluting our water supplies and leaving children with debilitating diseases." (MTBE is a gasoline additive used as an oxygenate and to raise the octane number. Its use has declined in the United States in response to environmental and health concerns since it is polluting groundwater due to MTBE-containing gasoline being spilled or leaked at gas stations) [6].

In India, the two holiest rivers Ganges and Cauvery are holist only by faith and not by purity. The Cooum, once a living river in Chennai City, Tamil Nadu state, India has turned into a biologically dead river because of raw sewage and garbage dumping- Figure 1 and Figure 2.

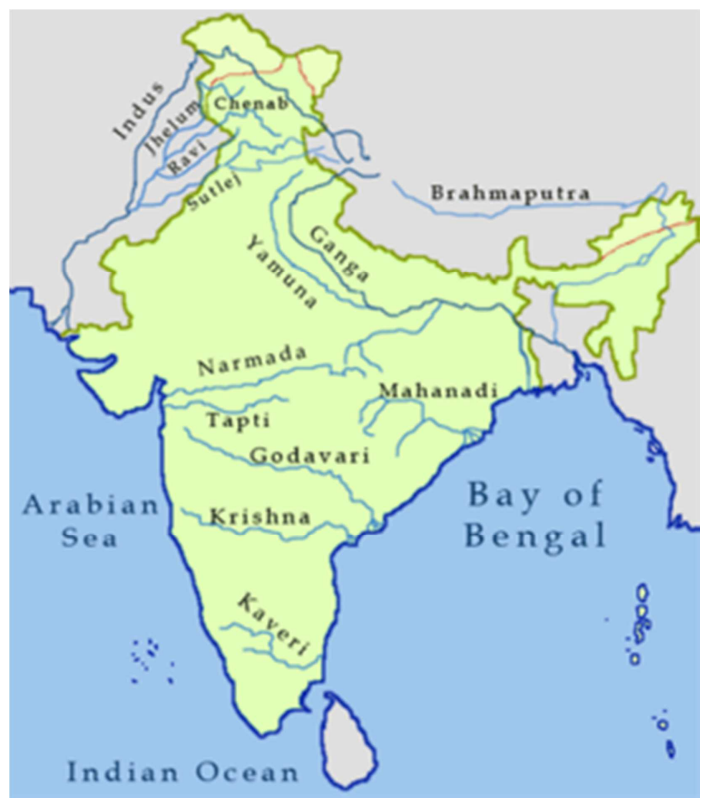

Figure 1. Major rivers in India.

Beware, the way and speed in which many rivers are polluted by raw sewage, in such a speed it may not be a wonder that all rivers might reach the status of Rio Nuevo in USA and they would turn filthy and unfit for human use shortly if sewage is not treated recycled to the tertiary level standard.

As we are all aware, some of the most advanced 
civilizations of the world have originated and flourished on the banks of major rivers and they have also been known by the names of the rivers. Apart from being sources of sustenance, rivers have also aided in transportation and trade. But they are struggling to biologically alive due to the human activity of allowing the raw and partially treated sewage of all origins into them without knowing there are 'the sources of life' to all lives on Erath.

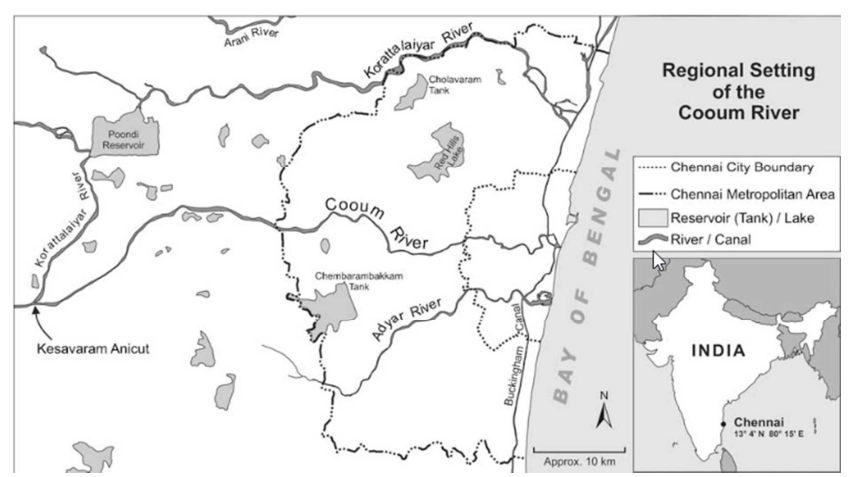

Figure 2. Cooum River in Chennai City, Tamil Nadu.

In the present context of pollution of air, water, land and the environment, people everywhere in the world should know, it is time to make the commitment in every nation to keep the raw sewage out of our water and environment.

After knowing, that the primary natural resource, the water, which sustains all lives on the Earth by producing all the natural resources in the lithosphere, biosphere, hydrosphere and atmosphere through different natural cycles, is under threat, by human influenced raw and partially treated sewage, as the author of this paper would like to suggest to treat the sewage to the acceptable standard and recycle it and thereby reserve the dwindling freshwater resource in the hydrologic cycle for the future use of our descendants. This is the main objective of this paper.

The other objective of this paper is limiting the freshwater use for some specific purposes and using the treated water for all nondomestic purposes with a new concept or hypothesis and thereby reserving the freshwater for future use in the preset context of freshwater stress in many nations.

We must all understand the basic truth, that sewage entered the earth only after our ancestors, the Homo sapiens, modern human beings as a species, in contrast to other species of ape entered about 200,000 years ago on earth. Prior to this there was no water in the hydrologic cycle in the name of sewage or wastewater. So, we, the descendants of Homo sapiens should remove the presence of sewage in the water cycle by treating and recycling.

\subsection{A Day Has Come to Conserve Freshwater by a New Hypothesis}

Since we have enough freshwater resource in the hydrologic cycle prior to the $21^{\text {st }}$ century, everyone thought that they would use freshwater for all their sectoral uses like domestic, agriculture, livestock, industry, energy etc. But that concept has now outdated today, since 2.2 billion people lack access to safely managed drinking water services and 4.2 billion people lack safely managed sanitation services as per UN study. Since many water scarcity countries are nearing to lose the last drop of freshwater as happened in Cape Town, South Africa in 2018 (In January 2018, when officials in Cape Town announced that the city of 4 million people was three months away from running out of municipal water, the world was stunned and labelled this scenario as "Day Zero" by local officials. But now it is slightly better) [7], the water scarcity nations have to think on a new path, a new hypothesis of recycling the treated sewage for nondomestic uses and thereby to reserve the freshwater for main uses like domestic and other uses which need freshwater alone and thereby to arrest the Day Zero freshwater scenarios even in the water rich nations.

\subsection{Other Options to Sustain Water Resources}

Though there are several water resources management paths, the most favorable water security pathways to attain water security are 1 . Flood and rainwater harvesting 2. Artificial groundwater recharge 3. Offseason tillage 4. Saving water in agriculture by micro irrigation practices 5 . Desalination 6. Enhancing irrigation efficiency 7. Rejuvenation of water bodies and 8 . Water sharing.

\section{Materials and Methods}

In the present context of physical and economic water scarcity as well as the human influenced pollution of freshwater and environment in many nations, water management practises are being adopted to overcome the scenario by bridging the water supply and demand gap as well as to protect the freshwater and ecosystems. Among the water management practices, treating and recycling the sewage for many nondomestic uses and saving the freshwater and protecting the environment play a big role now in many nations as we read below.

In many countries there is a difference between the wastewater generated and treated. The volume of wastewater treated in the Russian Federation is about $14 \mathrm{~km}^{3} /$ year. The estimated volume of wastewater generated in the Middle East and North Africa (MENA) region is $22.3 \mathrm{~km}^{3} /$ year, of which $51 \%\left(11.4 \mathrm{~km}^{3} /\right.$ year $)$ is treated. Most of the wastewater generated in Europe (71\%) undergoes treatment, partly due to high public awareness regarding health and environment protection, technological advancement for wastewater treatment methods, and investments by most governments in wastewater treatment systems. Only about $20 \%$ of generated wastewater undergoes treatment in the Latin American countries. The estimated volume of wastewater generated in North America each year is about $85 \mathrm{~km}^{3}$, of which $61 \mathrm{~km}^{3}$ are treated. Only about $32 \%$ of the wastewater generated in Asia is treated, largely due to the lack of treatment facilities in several counties [8].

Though the present sewage treatment in many regions are not encouraging we can be happy because, many regions and countries are entering in wastewater treatment after knowing 
it can be recycled and the environment can be protected.

But in the water scarce nations like Israel (treats and recycles more than 80 percent of its wastewater, using it primarily for agriculture, making it a world leader in that field) and in the Western States of USA, Australia etc., the treated sewage is mainly used for irrigation and other nondomestic uses and trying to protect their stinking environment.

The Yamuna River is sick and dying in some reaches and dead near Delhi, the Indian capital city due to the infilling of the domestic and industrial wastewaters as well as the dumping of solid wastes. Not only Yamuna River but there is many biologically dying, sick and dead rivers in India like Cooum river in Tamil Nadu State. The existing sewage treatment plants in the Yamuna River, need further improvement to a tertiary level standard. Then only it will be possible to recycle the treated water for some uses or allow it into the rivers as being done in Thames River and restore them biologically living rivers. The biologically dead Thames river where there was no fish at all in 1950s is now with 125 species. Sixty years ago, nothing could survive in the Thames - but today it is home to seals, porpoises and even the occasional stray whale.

Thus, Thames restoration is a unique model which can be practiced in any biologically dying, sick and dead rivers [9].

The polluted water in the waterways of Yamuna River basin-or in any dying, sick and dead river can be diluted, step by step by flushing during rainy seasons. In the course of time we can bring these rives to their original level by allowing only the treated water to an acceptable standard into the rivers.

Therefore, with the objective of treating and recycling the sewage in the Yamuna River basin similar to the above nations, the quantity of domestic and industrial pollution loads in the Yamuna River basin has been calculated. Twenty per cent of the domestic sewage is taken as the industrial pollution load. $80 \%$ of the water use for both these purposes is taken as the sewage load and for this quantity, the sewage treatment plants (STP) are decided, each at 20MLD capacity. The existing water quality scenario of the waterways and groundwater of this basin is discussed. Water resources both surface and groundwater of this basin has been also explained. This is the first time in the history of the Yamuna River basin, the volume of biogas and sludge generation, energy generation from biogas, quantity of freshwater saving and its value and the environmental benefits by sewage treatment are explained in this paper. The installation and maintenance cost of the sewage treatment plants (STP) are also calculated.

\section{Yamuna River Details}

The River Yamuna originates from the Yamunotri glacier, $6387 \mathrm{~m}$ above mean sea level, at the Banderpoonch peak in the Uttarkashi district of Uttarakhand-Figure 1. It is the most important river after the Ganga and has attracted much attention because Delhi, the capital of India, Agra, the city known for Taj Mahal and Mathura, the birthplace of Lord Krishna, are all located within a stretch of $200 \mathrm{~km}$ on its banks. It passes through certain areas of the seven States viz., Uttarakand, Uttar Pradesh, Haryana, Rajasthan, Madhya Pradesh, Himachal Pradesh and National Capital Territory of Delhi (NCT-Delhi). Yamuna is the sub-basin of the Ganga River system. Total length of the River Yamuna from its origin near Yamunotri to its confluence with Ganga River at Allahabad is 1,376kilometer. Out of the total catchment area of 8,61,404 sq km of the Ganga basin, the Yamuna River and its catchment together contribute to a total of $3,45,848 \mathrm{sq} . \mathrm{km}$ area (CPCB, 1980-81; CPCB, 1982-83). The river water is used for both abstractive and in stream uses like irrigation, domestic water supply, industrial etc. It has been subjected to over exploitation, both in quantity and quality. The Yamuna River traverses about $1370 \mathrm{~km}$ in the plain from Saharanpur district of Uttar Pradesh to the confluence with river Ganga at Allahabad. The major tributaries of the river are Tons, Betwa, Chambal, Ken and Sindh and these together contribute 70.9\% of the catchment area and balance $29.1 \%$ is the direct drainage of main River and smaller tributaries. The catchment basin of Yamuna River basin amounts to $40.2 \%$ of the Ganga Basin and $10.7 \%$ of the country [10], as is shown in Figure 3.

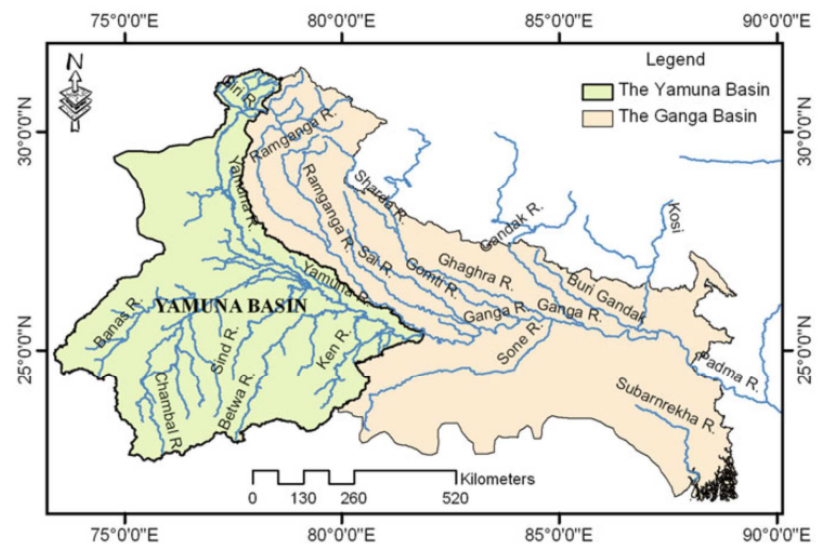

Figure 3. Yamuna River basin.

\subsection{Water Resources and Hydropower Potential of Yamuna River}

Annual average rainfall of Yamuna River basin from19512003 is $906.7 \mathrm{~mm}$ and the total surface water resource of the Yamuna River is $61,219.20$ million cubic metre [MCM] $/ 2161.93 \mathrm{TMC} / 61.22 \mathrm{~km}^{3}$ of which Chambal River contribution $43.667 \%, 26,736.60 \mathrm{MCM}$ followed by Betwa $19.28 \%, 11,802.90 \mathrm{MCM}$ Ken $13.21 \%, 8,089.40 \mathrm{MCM}$ and Sind $3.08 \%, 1,888.50 \mathrm{MCM}$. The annual flood water generation of this river is $580 \mathrm{MCM} / 20.48 \mathrm{TMC}$ of which $50 \%$ is not utilized but flows out of Delhi [11]. Groundwater recharge has been assessed using groundwater fluctuation of sedimentary and hard rock aquifers (crystalline and volcanic rocks) with their respective specific yield. Total annual groundwater potential for a unit refers to the available annual recharge after allowing the natural discharge during the 
monsoon and non-monsoon season through base flow and sub-surface inflow/outflow. Net groundwater availability is $45,428.8 \mathrm{MCM} / 1604.31 \mathrm{TMC} / 45.43 \mathrm{~km}^{3} \quad$ (total recharge 48,907.2MCM/48.91 $\mathrm{km}^{3}$ - groundwater flow $3,478.4 \mathrm{MCM} / 3.48 \mathrm{~km}^{3}$ ). The replenishable dynamic groundwater recharge of the Yamuna River flood plain in the $97 \mathrm{~km}^{2}$ area near Delhi is 7.2 million $\mathrm{m}^{3}$ per annum which is the very important source of water for Delhi's domestic water supply [12].

The rapid pace of urbanization adversely affected the water bodies in Delhi. The Central Ground Water Board assessed that total groundwater potential in Delhi has reduced from $428 \mathrm{MCM}$ in 1983 to $292 \mathrm{MCM}$ in 2003 . It indicates an overdraft and reduction of groundwater around 136MCM during the period of 20 years between 1983 and 2003 .

The total potential for hydropower development in the entire Yamuna basin is about 1300MW. The present utilization is only one third of total potential.

But the present water resource of this river is under threat due to human made pollution sources domestic sources like sewage, industrial effluents and solid wastes and hence the freshwater is dwindling not only in this river basin but also everywhere in the world.

\subsection{Pollution Level of Wastewater}

In addition, the above we must bear it in mind that one litre of wastewater could pollute 8 litres of freshwater. A single litre of used oil can contaminate a million litres of fresh groundwater as per the British Columbia Used Oil Management Association [13]. So, if the wastewater enters the water bodies, it will pollute a huge volume of freshwater. In addition to the above the untreated sewage mix with freshwater and drinking the contaminated water with sewage can affect the health of people and pollute the environment. From this fact we must understand the danger of the untreated sewage and hence wastewater treatment and recycling is need of the hour.

\section{Effects of Sewage Pollution}

A we are all aware the domestic sewage contains a wide variety of dissolved and suspended impurities. It amounts to a very small fraction of the sewage by weight, but it is large by volume and contains impurities such as organic materials and plant nutrients that tend to rot. The main organic materials are food and vegetable wastes. Plant nutrients come from chemical soaps, washing powders, etc. This sewage is also containing various substances that we use for keeping our houses clean add to water pollution because they contain harmful chemicals. Most detergents and washing powders contain phosphates which are used to soften the water, among other things.

Industrial wastewaters usually contain organic and inorganic matter in varying degrees of concentration. Since each chemical industry produces one or several type of chemicals the effluent naturally contain these chemicals. in this way several chemicals are coming out from the industry from the effluents. They may include toxic and other harmful materials as well as components that are non-biodegradable or that can reduce the efficiency of many wastewatertreatment operations. Therefore, comparing the domestic sewage, the industrial effluent is more dangerous. But sewage of any origin when enters water, land, air, ecosystems, and the environment it will affect all. So, if people drink the sewage contaminated water it will affect the health of people, animals and plants as well. Hence the time has ripened to treat and recycle the sewage for appropriate uses and thereby keep the freshwater in water bodies and aquifers biologically alive so that to use it for the future human civilization.

Globally about $381.19 \mathrm{~km}^{3}$ of water is used for domestic purposes for the 7736 million people supplying at 135 litre per capita per day as per the World Health Organization (WHO) standard and the sewage generation is $304.95 \mathrm{~km}^{3}$ ( $80 \%$ of water use) and in India about $67.51 \mathrm{~km}^{3}$ of water is used for domestic uses for the 1370 million people in the above year and standard and the sewage generation is 54 $\mathrm{km}^{3}$. In Tamil Nadu State in India in the same year for the present for the present population of 81.5 million people the domestic water consumption and sewage generation at above per capita rate is are $4.12 \mathrm{~km}^{3}$ and $3.31 \mathrm{~km}^{3}$ respectively. In addition to the domestic sewage a huge quantity of industrial effluents is also generated. As the polluted water from these two sources are let into the land and water bodies either without treatment or with partial treatment the ground and surface waters are being polluted everywhere in the world and hence the fresh water in the hydrologic cycle is decreasing.

\subsection{Sewage Contaminated Water on Health}

In Tamil Nadu state, India people used to drink the water from the drinking water tanks called Urani (a Tamil language word, meaning drinking water tank), in each village at least one tank is there solely for this use. None of these tanks are fit for this purpose now since they are all filled with water not from the direct rain but from the drainage from the agricultural fields with inorganic chemicals used as manure, weed killing chemicals, pesticides and also sewage flow to the tanks along with rain from the drainages in each village mixed with the human waste.

The sewage contaminated water has increased the risk of contracting illness due to bacteria and viruses present in sewage effluent. Gastrointestinal disorders have been linked to sewage pollution, with viruses implicated as the cause. Detergents can cause liver and kidney damage, while sewage water carries diseases such as Giardiasis, Amoebic dysentery and Cholera [14].

In 2012 , over 800,000 deaths worldwide were caused by contaminated drinking water, inadequate handwashing facilities and inappropriate sanitation services. In the seas and ocean, de-oxygenated dead zones caused by the discharge of untreated wastewater are growing rapidly, affecting an estimated $245,000 \mathrm{~km}^{2}$ of marine ecosystems, impacting on fisheries, livelihoods and food chains [15]. 


\subsection{Wastewater and Environmental Impact}

As we all aware water pollution has been increasing in most rivers in Africa, Asia and Latin America, due to the increasing amounts of wastewater entering the rivers as a result of population growth, increased economic activity and expanding agriculture, as well as the release of sewage with no (or only minimal levels of) treatment. Inadequate wastewater management has also a direct impact on ecosystems.

\subsection{Wastewater and Ecosystem Health}

The health of an ecosystem depends on the water, land, air and these natural resources are not affected by pollution, the biodiversity of each ecosystem will be normal. There are 17 ecosystems in the earth. Natural ecosystems are known as the kidneys of the environment and hence to keep the ecosystem environment clean, it is necessary to remove pollutants by regulating water flow and storing sediment. Keeping the ecosystem very effective and economical, it is necessary to provide wastewater treatment services, so that to make these ecosystems healthy by arresting all the pollutant load of the contaminants in the effluent by strict regulation, in such a way the pollution-carrying capacity of the ecosystem is not exceeded.

There are natural limits to the assimilative capacity of ecosystems, beyond which they are threatened and can no longer perform a purifying role. Once the concentration of contaminants in runoff reaches critical thresholds, there is a risk of abrupt and irreversible environmental change.

If the ecosystem health is protected by sewage treatment in every nation. each nation can get the economic value of water purification services similar to the Nakivubo Wetland (Uganda) where the value of the benefit has been estimated at between US\$980,000 and US\$1,808,000 per year, with additional co-benefits totaling US $\$ 200,000$ per year from crop cultivation, papyrus harvesting (a material prepared in ancient Egypt from the pithy stem of a water plant, used in sheets throughout the ancient Mediterranean world for writing or painting on and also for making rope), brick making and fish farming [16].

\subsection{Pollution and Biodiversity Loss}

As we are all aware biodiversity makes life livable on Earth by playing an important role in offering ecological services. The ecological services include air purification, replenishing and cleaning water systems, absorbing chemicals, stabilizing climate, recycling nutrients, and forming and protecting the soil. Crucial life cycles such as the hydrologic cycle and the nitrogen cycle are all determined by biodiversity. But these ecological services are under threat due to the various forms of pollution including water pollution, soil pollution, air pollution, land pollution and agricultural pollution all due to human impact simply destroy animal and plant habitats due to the toxic substances and chemicals released into the biological systems. Hence, some seriously polluted regions have become dead zones as the conditions cannot sustain any life form. Therefore, apart from habitat destruction, pollution poses long-term cumulative impacts on the species health, contributing to their eventual death. For instance, marine and freshwater life forms are most affected by pollution.

Biodiversity is significant because, it is responsible for the continuity of the planet since it supports majority of the vital environmental life cycles such as the oxygen cycle, the water cycle, and the nitrogen cycle, recycling the dead biological residues just to mention a few. With between 3 and 30 million species on earth, here are the reasons why they are important [17].

\subsection{Wastewater and Economic Effects}

Every farmer knows, the poor water quality hampers agricultural productivity in rural and peri-urban settings. Further contaminated water can directly affect economic activities that use water, such as industrial production, fisheries, aquaculture and tourism, and can indirectly limit the export of certain goods due to restrictions (and even bans) on contaminated products.

For example, in the Caribbean, many small island economies are almost entirely dependent on the health of their reefs for tourism, fisheries and shoreline protection [18], but these reefs are threatened by the discharge of untreated wastewater.

Pollution can also have an impact over business strategies and may cause some major environmental events which can result in the disruption of supply chains or an increase in the cost of raw material. Further, pollution of natural environments may hinder economic activities, tourism itself. Hence, organizations need to monitor such events and develop contingency plans to deal with them [19].

\subsection{Global Ecosystem Income}

Ecosystems provide food, freshwater, wood and fiber and fuel; it regulates climate, flood, disease and purify water and it helps for cultural activities like aesthetic, spiritual, recreational and educational. In this way ecosystems provide its services to the people and all the lives in the ecosystems and hence there is income to the world due to the above ecosystem services [20].

In 1997, the global value of ecosystem services was estimated to average \$33 trillion/year in 1995 \$US (\$46 trillion/year in 2007 \$US). In this paper, we provide an updated estimate based on updated unit ecosystem service values and land use change estimates between 1997 and 2011. We also address some of the critiques of the 1997 paper. Using the same methods as in the 1997 paper but with updated data, the estimate for the total global ecosystem services in 2011 is $\$ 125$ trillion/year (assuming updated unit values and changes to biome areas) and $\$ 145$ trillion/year (assuming only unit values changed), both in 2007 \$US. From this we estimated the loss of eco-services from 1997 to 2011 due to land use change at \$4.3-20.2 trillion/year, depending on which unit values are used [21]. Today every ecosystem is under threat due the influence of wastewater. 
The global loss of ecosystem service values places the cost between USD 6.3 and 10.6 trillion annually mainly due to land degradation [22]. But due to deforestation, pollution and acidification of sea etc., also the ecosystem income decreases.

The effects of water pollution are not only devastating to people but also to animals, fish, and birds alike. Polluted water is unsuitable for drinking, recreation, agriculture, and industry. It diminishes the aesthetic quality of lakes and rivers. More seriously, contaminated water destroys aquatic life and reduces its reproductive ability. Eventually, it is a hazard to human health. Nobody can escape the effects of water pollution. Treating the sewage in the sewage treatment plants (STP) and recycling is the key to minimize and arrest water pollution and protect the freshwater resources and thereby people and environment. Hence, to protect the freshwater resources and the environment of the Yamuna river basin it is suggested in this paper to treat and recycle the entire sewage of different origins.

\section{Pollution Level of Indian Water Bodies}

According to the study done by the Central Pollution Control Board (CPCB) the raw sewage and industrial waste rendered water in more than half of India's 445 rivers unfit for drinking and other uses. The study compared pollution levels from 1995 to 2011 including the rivers as well as 154 lakes and 78 ponds in the second-most populous nation, India. In the $12,363 \mathrm{~km}$ length of pollution study done in the 290 rivers of among the 445 rivers in India, 275 rivers have highly polluted water and in the above total length of water quality study, the $8,500 \mathrm{~km}$ length, that is $68.75 \%$ stretches have severely polluted water with high organic pollution, measured in terms of biological oxygen demand (BOD) levels higher than 10 (3 or less being the safety standard). Water from at least a quarter of the rivers surveyed cannot even be used for bathing. Only 29 percent of municipal wastewater is treated by Indian cities of 38 billion liters (10 billion gallons) generated every day, according to the report. By 2050, 100billion liters of wastewater may come from Indian cities each day, it said. It works out to $100 \mathrm{MCM} / 3.53 \mathrm{TMC}$ per day and $1,288.98 \mathrm{TMC} / 36.50 \mathrm{~km}^{3}$ per annum. Hence, India will need "considerable" investments in wastewater management to meet demands of growing urban populations. The CPCB has identified 764 Grossly Polluting Industries in the States on the main stems of Ganga and its tributaries Kali-East and Ram Ganga.

In India there is no $100 \%$ freshwater river but there is only gradation of water pollution from low to high. Even the sacred rivers, the Ganges, Yamuna and Cauvery are not sacred now. According to $\mathrm{CPCB}$, the following rivers are polluted in their entire length but the most polluted stretches are: Yamuna from Delhi to Agra, Hindon from Saharanpur to Ghaziabad, Mithi in Mumbai, Godavari in Maharashtra, Sabarmati in Ahmadabad, Damanganga in Daman and Diu, Umkhrah in Shillong, Gaggar in Punjab, Cooum in the entire stretch and Cauvery in all the city reaches in Tamil Nadu.
Hence the decline in the quantity and quality of water flow has reduced the productivity of many terrestrial, aquatic, and coastal zone ecosystems and led to loss of biodiversity. This means, $8,500 \mathrm{~km}$ of these rivers are badly polluted and not fit to support aquatic life. The bad news goes much beyond that: the number of polluted water zones in India has increased manifold over the past two decades. In addition, the pollution load on rivers has been rising constantly. The report says over 370 major towns and cities are contributing to river pollution as the country has the wherewithal to treat only $30 \%$ of its urban water waste.

Among the Indian rivers the most polluted and sinking rivers are the Yamuna in Delhi, Coovum and Adayar rivers in Chennai city, Tamil Nadu State. Delhi uses about 36.71TMC of domestic water per annum at the per capita per day rate of 160 litres (per day water use is $0.101 \mathrm{TMC}$ or $2.85 \mathrm{MCM}$ ). Delhi city is now generating 29.37TMC of domestic sewage per annum. In addition to the domestic sewage Yamuna River is also polluted by industrial effluents.

\subsection{Yamuna River Basin Pollution Scenario}

Post-independence, swift industrial development occurred across the Yamuna River basin. There are huge number of industrial clusters at various places including Indore, Gwalior, Kota, Khetri, Panipat, Yamuna Nagar, Nagda, Delhi, Baghpat, Sonepat, Ghaziabad, NOIDA, Mathura Faridabad and other places. These different industries discharging wastewater into Yamuna River comprises of distilleries, pulp, sugar, weaving, oil refineries, chemical, drugs, thermal power plants, foodstuff industries etc. There are unchecked and unrestricted numbers of industries, throwing huge amount of unprocessed effluents in Yamuna prevailing in Faridabad, Delhi, Agra and Mathura. A barrage $200 \mathrm{~km}$ upstream of Delhi, the diversion through the Agra canal of the wastewater from Delhi and extensive channelization has resulted in the nearly complete withdrawal of water from the river. This together with heavy discharge of untreated domestic and industrial effluents has turned the river into a sewer at least between Delhi and Agra. According to CPCB survey, approximately 350 industrial units that throw their waste wastes in Yamuna of which more than forty are in Delhi (Water Quality Status of Yamuna River (1999-2005). Due to the above pollution load Yamuna River has become murky river and river of sadness to the areas around with special reference to Mathura, Delhi, and Agra. The color of Yamuna River is awfully dark, it looks virtually like a gutter in NCT, as most of the manufacturing and other engineering units are situated on its bank and at one time used to junk and throw the unprocessed wastes into the Yamuna. The River water remains immobile for nearly three-fourth time of a year [23]. But effective steps to improve the water quality of this river is lacking even today.

The river Yamuna, the lifeline of Delhi, is gradually dying now due to the rampant industrial effluent and untreated sewage which are choking the river. Despite government norms, the sewage treatment plants continue to be underutilized. The city generates 650million gallons of 
sewage per day against an installed capacity of 512 million gallons. But only 350million gallons of sewage reaches the treatment plants. A deadline of 2012 has been set to ensure no untreated sewage goes into the river. Efforts are also on to check the pollution levels from the neighbouring state of Haryana.

The Yamuna is choking to death primarily because untreated waste is flowing into it from several cities along its banks in Haryana and Uttar Pradesh. The river's contamination starts in Haryana and continues in Delhi, ultimately making it almost invisible in Uttar Pradesh where it merges with the Ganga in Allahabad. The CPCB report warns of far-reaching consequences if India fails to enhance its capacity to treat urban waste-which stands at 38,000 million tons a day [24].

Given that a large population is dependent on the Yamuna River, it is of significance to preserve its water quality. The river is polluted by both point and non-point sources, where NCT is the major contributor, followed by Agra and Mathura. Approximately, $85 \%$ of the total pollution is from domestic source. The condition deteriorates further due to significant water abstraction which reduces the dilution capacity of the river. The stretch between Wazirabad barrage and Chambal River confluence is critically polluted and $22 \mathrm{~km}$ of Delhi stretch is the maximum polluted amongst all.

In 1909 the waters of the Yamuna were distinguishable as "clear blue", as compared to the silt-laden yellow of the Ganges. However, due to high density population growth and rapid industrialization today Yamuna is one of the most polluted rivers in the world, especially around New Delhi, the capital of India, which dumps about $58 \%$ of its waste into the river. Delhi generates approximately 600 million gallons per day (MGD) of sewage, while it has an installed capacity to treat approximately $512.4 \mathrm{MGD}$ of waste. Nearly $58 \%$ of the total sewage generated by the city is dumped in the Yamuna, emptied into the river by 22 sewage drains between Wazirabad Barrage and Okhla Barrage.

Najafgarh drain is the biggest drain in Delhi and contributes about $60 \%$ of the total wastewater that gets discharged from Delhi into river Yamuna. The drain traverses a length of $51 \mathrm{~km}$ before joining river Yamuna and is unlined for about $31 \mathrm{~km}$ along its initial stretch.

In 2008, the water quality monitoring found that almost all rivers in India are with high levels of biological oxygen demand (BOD). The worst pollution, in decreasing order, were found in river Markanda $(590 \mathrm{mg} \mathrm{O} / \mathrm{L}=$ oxygen per litre), followed by river Kali (364), river Amlakhadi (353 mg $\mathrm{O} / \mathrm{L})$, Yamuna canal $(247 \mathrm{mg} \mathrm{O} / \mathrm{L})$, river Yamuna at Delhi (70 $\mathrm{mg} \mathrm{O} / \mathrm{L}$ ) and river Betwa $(58 \mathrm{mg} \mathrm{O} / \mathrm{L})$. In this context, a water sample with a 5 day BOD between 1 and $2 \mathrm{mg}$ Oxygen/Litre $(\mathrm{O} / \mathrm{L})$ indicates a very clean water, 3 to $8 \mathrm{mg}$ $\mathrm{O} / \mathrm{L}$ indicates a moderately clean water, 8 to 20 indicates borderline water, and greater than $20 \mathrm{mg} \mathrm{O} / \mathrm{L}$ indicates ecologically-unsafe polluted water.

The pollution load of Ganga River is 2,538 million litre per day (MLD) and the pollution load in Yamuna River is 3,500MLD during 2007. As per the Central Pollution Control
Board's latest estimate out of 22,900MLD of wastewater generated, only about 5,900MLD (26\%) is treated before letting out, the rest i.e., 17,000MLD is disposed of untreated in the 299 class I cities in India. Twenty-seven cities have only primary treatment facilities and forty-nine have primary and secondary treatment facilities. The level of treatment available in cities with existing treatment plant varies from $2.5 \%$ to $89 \%$ of the sewage generated.

Rivers Yamuna, Ganga, Gomti, Ghaggar, Chambal, Mahi, Vardha are amongst the other most coliform polluted water bodies in India. For context, coliform must be below 104 MPN/100 ml, (MPN=most probable number per 100 millilitres) preferably absent from water for it to be considered safe for general human use, and for irrigation where coliform may cause disease outbreak from contaminated water in agriculture. In 2006, 47 percent of water quality monitoring, the coliform levels in India is highly reported a total average annual coliform level above $500 \mathrm{MPN} / 100 \mathrm{ml}$. During 2008, 33 percent of all water quality monitoring stations reported a total coliform level exceeding those levels, suggesting recent effort to add pollution control infrastructure and upgrade treatment plants in India, may be reversing the water pollution trend.

Dissolved oxygen (DO) levels, necessary to support aquatic life, range between $0.0 \mathrm{mg} / \mathrm{L}$ and $3.7 \mathrm{mg} / \mathrm{L}$ the Yamuna from Wazirabad Barrage in Delhi to Agra. The minimum should be $4.0 \mathrm{mg} / \mathrm{L}$. Biochemical oxygen demand (BOD) levels, a key measure of water pollution, have increased between Panipat and Agra. This is due to hundreds of drains that dump untreated sewage in the river between these reaches. The BOD concentration in this stretch has been found to be $4.99 \mathrm{mg} / \mathrm{L}$ against the permissible $3 \mathrm{mg} / \mathrm{L}$ or less. Ammonia, which is toxic to fish and other aquatic life, is present in high levels between Nizamuddin Bridge and Agra. Coliform bacteria levels, a pointer of bacterial pollution in a river, too have increased between Panipat and Agra [25].

Monitoring data shows that pollution measured in terms of BOD load has increased 2.5 times from 1980-2005. BOD load, which was 117 tonnes per day (tpd) in 1980 increased to 276 tpd in 2005. Since the Yamuna River has no freshwater flow for virtually nine months, it is not possible to flush the sewage load during this period and hence foul smell and stinking. Delhi impounds water at the barrage constructed at Wazirabad. Water that flows subsequently is only sewage and waste. The anaerobic condition in the river is frequently observed and as evident from the presence of masses of rising sludge from the bottom, gas bubbles and floating solids on the surface [26].

Groundwater along Najafgarh drain is contaminated in stretches and the area is not suitable for large-scale groundwater development for drinking water purposes. The groundwater quality almost in the entire stretch of lands adjacent to the Yamuna River is under various stages of pollution due to the seepage of the sewage water of this river. 


\subsection{Religious and Social Practices}

People do many religious activities like Asthi visarjan (ashes immersion), Murti visarjan (Idol immersion) Deh visarjan (dead bodies of human beings' immersion) on the bank of the river Yamuna. Poly bags filled with different holy material are also immersed into the river. These religious activities are also polluting not only Yamuna but also many rivers of religious importance.

\section{Restoration History of Yamuna River}

To address river pollution, certain measures of river cleaning have been taken by the Government's Ministry of Environment and Forests in 12 towns of Haryana, 8 towns of Uttar Pradesh, and Delhi, under the Yamuna Action Plan which has been implemented since 1993 by the National River Conservation Directorate of the Ministry of Environment and Forests. The Japan Bank for International Cooperation is participating in the Yamuna Action Plan in 15 of the above 21 towns with soft loan assistance of 17.773billion Japanese Yen (equivalent to about Rs. 700crore) while the Government of India is providing the funds for the remaining 6 towns.

In 2009, the Union government admitted to the Lok Sabha (Indian Parliament), the failure of the Ganga Action Plan (GAP) and the Yamuna Action Plan (YAP), saying that "rivers Ganga and Yamuna are no cleaner now than two decades ago" despite spending over Rs 1,700crore to control pollution. To carry out proper cleaning huge sum of money and a 24-hour power supply were needed to manage similar to Thames River wastewater treatment plants, while only an 8-hour power supply was available, contributing to the failure of both river plans. In August 2009, the Delhi Jal Board (DJB) initiated its plan for resuscitating the Yamuna's $22 \mathrm{~km}$ stretch in Delhi by constructing interceptor sewers, at the cost of about Rs 1,800crore.

Even after spending huge fund in the past two decades to clean the Yamuna, which meets 70 per cent of Delhi's daily water needs, has all been a waste. The CPCB report says the polluted length of the river has increased from $500 \mathrm{~km}$ to $600 \mathrm{~km}$ even after treatment indicating the poor treatment.

According to the Press Trust of India, (December 2013) the Minister of Environment and Forests informed in the Parliament that the Government of India so far allotted and almost spent Rs. 14,704.23crores to arrest pollution in Indian rivers (Ganga River restoration Rs. 8,856.96cores, for National River Conservation Plan covering 39 rivers in 185 towns in 20 States Rs. 4,475crores and for Yamuna River restoration Rs1,372.27crores). Though India has spent so much money to clean up the rivers (year wise correct expenditure is not available), not even a single river including the Yamuna has been restored and they continue to be polluted due to garbage and the sewage treatment facilities are underfunded or malfunctioning. The Yamuna continues to be stagnant for almost nine months in a year, aggravating the situation.
As per GN Bureau, [27], at present Japan International Cooperation Agency (JICA) assisted Yamuna Action Plan (YAP) Phase-III project is under implementation at an estimated cost of Rs 1,656 crore in Delhi for rehabilitation and up-gradation of existing Sewage Treatment Plants (950 million litres per day) and Trunk sewers (43 kms) in Delhi. Delhi Jal Board is the implementing agency. The duration of YAP-III project is 7 years. If the same old practice of no treatment, or partial treatment of sewage, the allocation of fund in the III YAP project would be an infructuous expenditure.

The Yamuna's polluted stretch was about $500 \mathrm{~km}$ - from Wazirabad in Delhi Juhika in the river's downstream near Etawah in Uttar Pradesh, according to Central Pollution Control Board's (CPCB) 2010 data. But latest data show the pollution now starts from Panipat in Haryana, almost $100 \mathrm{~km}$ upstream of Wazirabad. The efforts of Haryana, Uttar Pradesh and Delhi to improve the quality of Yamuna's water are not showing any results," says the report obtained by Manoj Mishra of Non-Governmental Organization Yamuna Jiye Abhiyan in response to Right to Information (RTI) query. The report, submitted as an affidavit before the Supreme Court by the CPCB, says all parameters used to test water quality indicate the Yamuna's water from Panipat to Agra contains high levels of pollutants. This stretch was believed to be clean and pollution-free till recently.

Harmful religious and social practices (cremation of dead bodies on the bank of rivers, throwing of un-burnt or halfburnt bodies into the rivers, dead bodies ash immersion, mass bathing in the rivers, idol immersion in the rivers, throwing of animal carcasses) are also the reasons for the pollution of Indian rivers in addition to sewage.

\subsection{Lessons Learnt from the Yamuna River Restoration}

Though the Government of India initiated action to restore the water quality of Yamuna river by the Yamuna Action Plan (YAP) in the1993and later YAPII in the year 2004, the result is a failure. Hence Yamuna River is almost dead due to the pollution load from sewage and industrial effluents. To restore Yamuna periodically huge money is being spent but the restoration is eluding. This is due to the improper planning either due to non-treatment or partial treatment of the sewage. To bring this river to the original level we need to treat the entire sewage loads of all origins to the tertiary level standard and then only recycle it for other than domestic uses or allowing it into the river as per the Thames River restoration model where all the sources of sewage water and solid wastes normally dumped into this river are treated and recycled.

\subsection{Bringing Treated Sewage to the Drinking Water Standard}

Now several technologies are used to recycle wastewater, depending on the purity we need and the purposes. The sewage is now brought to the standard of drinking by preliminary, primary, secondary, tertiary and advanced stages 
of treatment through microfiltration, reverse osmosis and UV light. By the time it leaves the plant, it is distilled water fit for drinking. Now Singapore, Australia, Namibia and States such as California, Virginia and New Mexico are already drinking recycled water, demonstrating that purified wastewater by STP can be safe and clean, and help to ease water shortages [28]. California's Orange County Water District (OCWD) has a plant that recycles the used water and returns it to the drinking supply. It is expanding production to 100 million gallons per day, enough for 8,50,000 people [29]. The World Water Council projects that recycled sewage will be a normalized source of drinking water in cities around the world within 30 years, and much of the infrastructure and technology is already in place.

After seeing the success stories of water treatment and recycling potential from the above two references, the authors would like to suggest to the Indian Government that the waterways in the Yamuna River basin in various pathetic status of pollution like-sick, dying and biologically dead could be brought to the original status by proper treatment and recycling of all sources of pollution load. To decide the STPs the sewage load of the entire Yamuna River basin has been assessed both for domestic sewage and industrial effluents.

\subsection{Estimation of the Sewage Load in the Yamuna River Basin}

At the per capita per day water use of 160 litres in Delhi city, the water use per day in this city for the 2011 population of 17.8 million is $2,848 \mathrm{MLD}$ and the annul water use is $36.71 \mathrm{TMC} / 1.04 \mathrm{~km}^{3}$. Total population of Yamuna River basin including Delhi is 200.38million. Leaving Delhi population, the remaining population of this basin is 182.58 million. At the WHO rate of $135 \mathrm{lpcd}$ the water generation per day is 24,648.30 MLD and the annual water use is $317.71 \mathrm{TMC} / 8.99 \mathrm{~km}^{3} .80 \%$ of the water use is taken as the sewage water generation. So, the wastewater generation in Yamuna River basin is $21,997.04 \mathrm{MLD}$ including Delhi city and the annual water use for domestic use is $283.54 \mathrm{TMC} / 8.03 \mathrm{~km}^{3}$. Normally $20 \%$ of domestic use is generated for industrial use in an industrial river basin like Yamuna and hence on the safer side we can take the industrial effluent in Yamuna River basin as 4,399.48MLD. Therefore, the total sewage generation in this river basin is likely to be $26,396.52 \mathrm{MLD}$ for the annual water use of $340.25 \mathrm{TMC} / 9.63 \mathrm{~km}^{3}$.

\subsection{Installation and Maintenance Cost of the Sewage Treatment Plants}

At the rate of 20MLD per STP, the number of STPs required to treat the $26,396.52 \mathrm{MLD}$ of sewage in this basin is 1,320. But actual field study is necessary to assess the treatment plants needed. The 20MLD capacity can be high or low depending upon the sewage generation in each area. Villages are to be grouped before deciding the plant capacity. The sewage load from each village can be taken to the plant by pipes or through tankers and the entire pollution load of this river should be treated by tertiary level treatment plants. Further, the hospital and Chemical industries sewage must be brought to the standard of the common effluent wastewater by appropriate special type of treatment and then only allowed into the STPs. Along with treatment and recycling the sewage, the waterways are also to be effectively flushed with the rainwater during every normal monsoon season.

At the rate of about Rs. 170million/ $\$ 2.43$ million per STP, cost of 1,320 plants for erection and commissioning excluding operation and maintenance is Rs. 22,440 million/\$320.57million. The annual maintenance of these plants at Rs. 7.6 million $/ \$ 108,571$ per plant is Rs. 10,070million/\$143.86 million.

\section{Benefits of Sewage Treatment and Recycling}

The author of this paper is suggesting to the Indian Government to treat the entire sewage load of the Yamuna River basin to the tertiary level standard, so that to purify and bring it to a recyclable standard of the treated sewage to facilitate for nondomestic uses. The purpose of tertiary level treatment for Yamuna River basin sewage is, to provide a final treatment stage to raise the effluent quality to the desired level as well as to use the byproducts produced during the process of treatment for human needs. This advanced treatment can be accomplished by a variety of methods such as coagulation, sedimentation, filtration, reverse osmosis, and extending secondary biological treatment to further stabilize oxygen-demanding substances or remove nutrients. In various combinations, these processes can achieve any degree of pollution control desired. As wastewater is purified to higher and higher degrees by such advanced treatment processes, the treated effluent can be reused for non-domestic urban, landscape, and agricultural irrigation, industrial cooling and processing, recreational uses and groundwater recharge, and even indirect and direct augmentation of drinking water supplies.

A treatment scheme for a 20MLD sewage treatment plant is provided in-Figure 3 . The different units of the treatment plant would have the following dimensions: Inlet chamber: $3 \mathrm{~m} \times 2 \mathrm{~m} \times 6 \mathrm{~m}$ depth; Detritus tank: $10 \mathrm{~m} \times 10 \mathrm{~m} \times 0.92 \mathrm{~m}$; Primary clarifier: $21.4 \mathrm{dia} / 2.4 \mathrm{~m}$ depth; Primary digester: 21.4mdia/6.1m height; Secondary digester: $21.4 \mathrm{~m} \mathrm{dia} / 6.1 \mathrm{~m}$ height; Aeration tank: $40 \mathrm{~m} \times 10 \mathrm{~m} \times 3.8 \mathrm{~m}$ depth; Sludge drying bed: $30.5 \mathrm{~m}$ x $11.6 \mathrm{~m}$; Secondary clarifier: $24.4 \mathrm{~m}$ dia $\times$ $2.4 \mathrm{~m}$ depth.

After primary and secondary treatment, the wastewater will be subjected to tertiary treatment involving microfiltration (MF) (pore size: $0.2 \mathrm{um}$ ) for the removal of fine particles and microbes and then demineralized in 5MLD Reverse Osmosis (RO) plants for 80\% recovery. Chlorine may be added before and after MF treatment. The RO permeate is disinfected by ultraviolet irradiation using UV units in series equipped with UV lamps. 
For organic pollution the treatment efficiencies that define a tertiary treatment are the following: organic pollution removal of at least $95 \%$ for BOD and $85 \%$ for $\mathrm{COD}$, and at least one of the following: 1 . Nitrogen removal of at least $70 \% 2$. Phosphorus removal of at least $80 \% 3$.
Microbiological removal achieving a faecal coliform density less than 1000 in $100 \mathrm{~mL}$ and 4. Colour removal. Thus, the treated sewage characteristics could be brought to: BOD $\mathrm{mg} / \mathrm{L}\left(5\right.$ days at $\left.20^{\circ} \mathrm{C}\right)<20$, COD $\mathrm{mg} / \mathrm{L}<100$, TSS $\mathrm{mg} / \mathrm{L} 30$, Oil and grease mg/L 10-Figure 4.

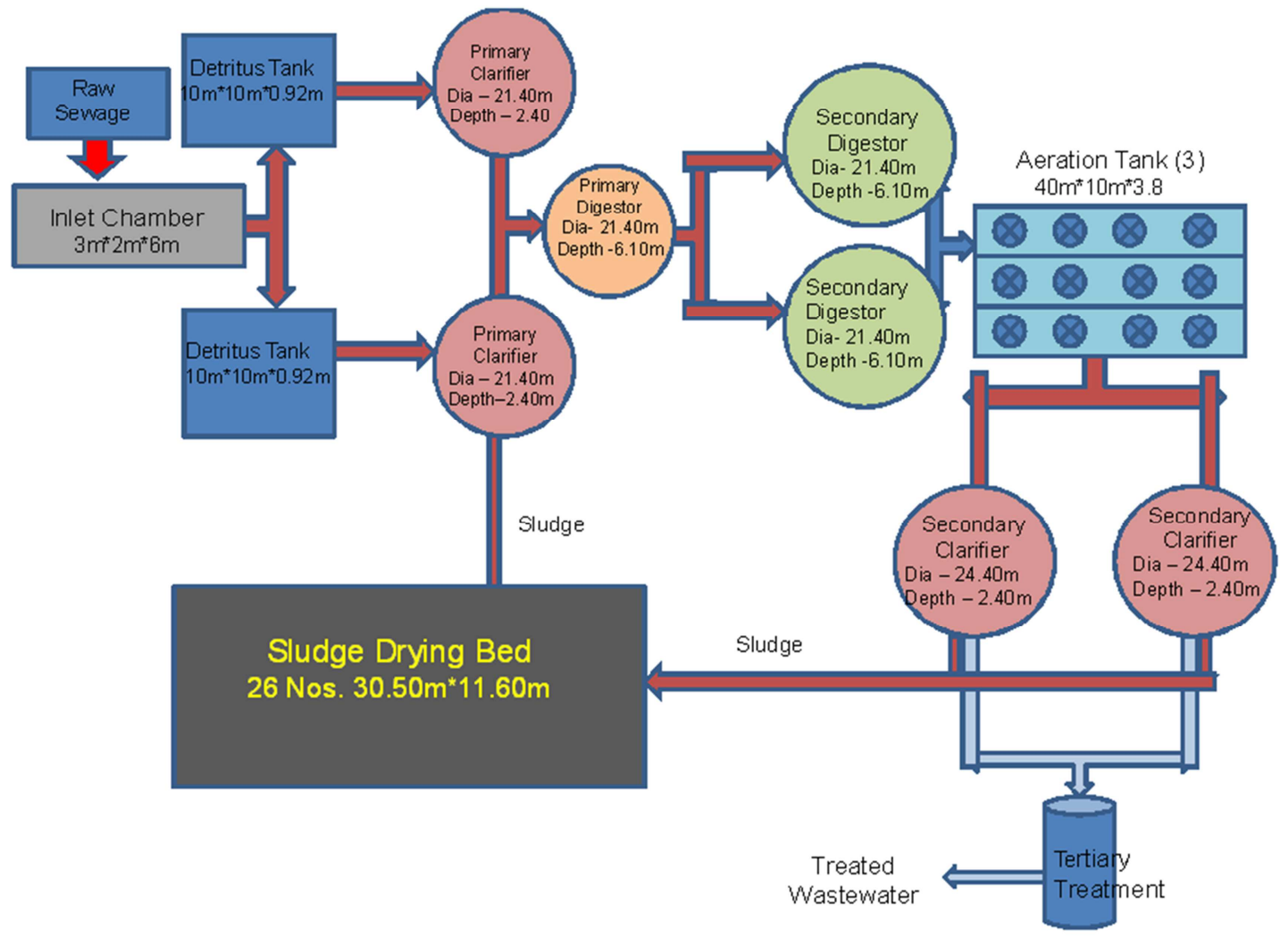

Figure 4. Flow chart showing the primary, secondary and tertiary treatment of raw sewage.

From the proposed sewage treatment plants in the Yamuna river basin, about $1,156.32$ million $\mathrm{m}^{3}$ of biogas can be produced per annum at the rate of $2400 \mathrm{~m}^{3}$ of biogas per day per plant. At the rate of $4800 \mathrm{kwh}$ per day per plant, about 2,312.64million kwh energy can be produced per annum [3032]. At Rs. 3.5 per kwh, the total cost of the electricity generation from these STP is Rs. 8, 044.24million/114.92million per annum. The biogas can be used for running the plant directly for cooking through pipes or for power generation. At the rate of 900tons of sludge per plant per day about 433.62 million tons can be generated per annum and used of agriculture with suitable amendments.

Use of sewage sludge as a soil enhancer and fertilizer on agricultural land remains the environmentally acceptable option, with around $80 \%$ being applied to agricultural land. The reutilization of sewage sludge to land is regulated under the Sludge (Use in Agriculture) Regulations 1989 (as amended) in United Kingdom. A voluntary agreement known as the 'Safe Sludge Matrix' ensures that sludge is only recycled to certain crops and vegetation to avoid human health impacts from ingestion of pathogen-contaminated salad crops. Hence, the 433.62 million $\mathrm{m}^{3}$ of sludge per annum produced from the 1,320 STPs can be used as manure for certain crops. Even it is supplied free of cost to farmers, nothing is wrong since it increases the crop production without spending money, and it would arrest the stinking of environment and reduce the cost of silt and mud cleaning from the waterways -Table 1.

Table 1. Benefits of wastewater treatment and recycling.

\begin{tabular}{|c|c|c|}
\hline By products from sewage treatment & Volume in million $\mathrm{m}^{3}$ & Cost Rs. in million \\
\hline Biogas (Methane) & $1,156.32$ & \\
\hline Converting biogas into electricity, at $2 \mathrm{kwh}$ per $\mathrm{m}^{3}$ & 2,312.64millionkwh & $8,044.24$ \\
\hline Sludge & 433.62 & Free cost \\
\hline $\begin{array}{l}\text { From toilet flushing at } 35 \text { lpcd for } 20.38 \text { million } \\
\text { people }\end{array}$ & 91.41TMC per annum & $\begin{array}{l}\text { Rs. } 383,978.18 \text { million } / \$, 5485.40 \text { million at Rs. } 1800 \text { per } 12,000 \text { litres } \\
\text { a lorry load of water per day per annum }\end{array}$ \\
\hline $\begin{array}{l}\text { Non-domestic urban, landscape, and agricultural } \\
\text { irrigation, industrial cooling and }\end{array}$ & 249.84TMC & $\begin{array}{l}\text { Rs. } 10,61,2017.15 \text { million} / \$ 15,160.10 \text { million at Rs. } 1800 \text { per } \\
1800 / \$ 25.71 \text { per } 12,000 \text { litres a lorry load of water per day per } \\
\text { annum }\end{array}$ \\
\hline
\end{tabular}


Increasingly the sewage sludge generated from treatment processes has undergone anaerobic digestion with around $75 \%$ of sewage sludge currently processed this way. Anaerobic digestion reduces the residual sewage solids that needs to be disposed of and generates the by-product of biogas, a renewable energy source. For smaller sewage sludge processing facilities, the biogas collected is typically used to heat the digesters to improve the digestion process. At larger facilities STPs, biogas can be conveyed off-site for use in Combined Heat and Power plants to generate electricity for general use by export to the national grid. Technological developments also mean biomethane (processed biogas) can be injected into the national gas grid or used as a fuel for vehicles. Even when incinerated, sewage sludge can be used as fuel to generate energy. [33]

Since wastewater is being generated every second globally, it is necessary to reclaim the scarce resource and allow it only after full treatment into the waterways and use it for appropriate purposes and ease the water demand of the city like Delhi in the Yamuna River basin. Even for toilet flushing also freshwater is used. By using the treated water for toilet flushing at $35 \mathrm{lpcd}$ we can save about $90.41 \mathrm{TMC} / 2.56 \mathrm{~km}^{3}$ of water per annum for the present population of 200.38 million people of this basin. The value of 90.41TMC of conserved water is Rs. 3,83,978.18 million (\$6,399.64million) per annum at the present rate of Rs. $1,800 / \$ 25.71$ per 12,000 litres of a lorry load of fresh water in Chennai city, Tamil Nadu. In this way each citizen can save Rs. 1,916 annum $/ \$ 27.37$ and Rs. $5.25 / \$ 7.5$ cents per day. The value of the $6.93 \mathrm{~km}^{3}$ of fresh water conserved per annum in Yamuna River basin works out to Rs. $14,45,185.33$ million ( $\$ 24,086.42$ million $/ \$ 344.09$ million) at the above rate of the freshwater-Table 1. By proper treatment and recycling the sewage for different uses as well as allowing it into the waterways, it is possible to bring the Yamuna River basin clean and disprove "Clean Yamuna River is a pipe dream". If the government of India does not act to treat and recycle the sewage to the acceptable standard, River Yamuna is 'close to death' as per Neetu Chandra Sharma [34].

In India as on 28th May 2018 in the total wastewater generation of 61,754 MLD in cities, equal to 22.54 cubic kilometer sewage per annum, the untreated sewage was 38,791 MLD, $62.82 \%$ and the treated sewage was only 22,963 MLD, just 38.18\% [35]-Figure 5.

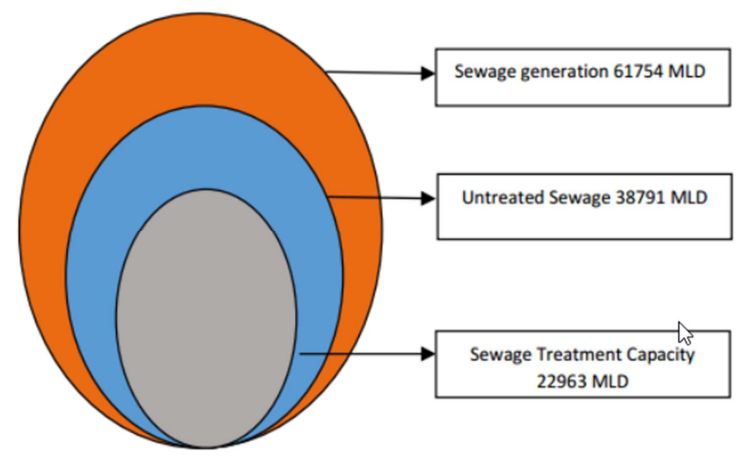

Figure 5. Sewage generation and treatment in cities as on as on 28th May 2018 in India.
The main reason, the Ganges and Yamuna rivers are sick and dying in many reaches even after spending several crores of rupees, because, the treated water is not to the tertiary level standard. If all the sewage in the entire nation is not treated to the tertiary level standard and recycled, just in a decade or two, all the water bodies in India are likely to be polluted and die as the Cooum river in Chennai city.

\section{Recycling Opportunities for Treated Water}

The Environmental Protection Agency (EPA) of USA has done lot of study on recycling the treated water. This study is likely to help many nations to use the treated water for the beneficial uses of people. After knowing this fact, the author is explaining below the various opportunities available to recycle the treated water for the benefit of humans and environment.

Recycled water is most commonly used for agriculture, landscape, public parks, and golf course irrigation and not for drinking. Other non-potable applications include cooling water for power plants and oil refineries, industrial process water for such facilities as paper mills and carpet dyers, toilet flushing, dust control, construction activities, concrete mixing, and artificial lakes.

Although most water recycling projects have been developed to meet non-potable water demands, several projects use recycled water indirectly for potable purposes. These projects include recharging groundwater aquifers and augmenting surface water reservoirs with recycled water. In groundwater recharge projects, recycled water can be spread or injected into aquifers to augment groundwater supplies, and to prevent saltwater intrusion in coastal areas. For example, since 1976, the Water Factory 21 Direct Injection Project, located in Orange County, California, has been injecting highly treated recycled water into the aquifer to prevent saltwater intrusion, while augmenting the potable ground water supply.

In addition to providing a dependable, locally controlled water supply, water recycling provides tremendous environmental benefits such as providing an additional source of water, water recycling can help us find ways to decrease the diversion of water from sensitive ecosystems, decreasing wastewater discharges and reducing and preventing pollution, recycled water can also be used to create or enhance wetlands and riparian habitats and to save energy etc.

\subsection{Recycling Provides Additional Source of Water}

People who reuse water can supplement their demands by using a reliable source of recycled water, which can free considerable amounts of water for the environment and increase flows to vital ecosystems.

\subsection{Dried Streams Can be Rejuvenated by Treater Water}

Wetlands provide many benefits, which include wildlife 
and wildfowl habitat, water quality improvement, flood diminishment, and fisheries breeding grounds. For streams that have been impaired or dried from water diversion, water flow can be augmented with recycled water to sustain and improve the aquatic and wildlife habitat

\subsection{Treated Water Can Prevent Pollution and Reduce Synthetic Fertilizers}

When untreated sewage is discharged to oceans, rivers, and other water bodies they are curtailed. But treated water cannot pollute these water bodies. The recycled water may contain higher levels of nutrients, such as nitrogen, than potable water and hence application of recycled water for agricultural and landscape irrigation can provide an additional source of nutrients and lessen the need to apply synthetic fertilizers.

\subsection{Treated Water Can Save Energy}

As the demand for water grows, more water is extracted, treated, and transported sometimes over great distances which can require a lot of energy. If the local source of water is groundwater, the level of groundwater becomes lower as more water is removed, and this increases the energy required to pump the water to the surface. Recycling water on site or nearby reduces the energy needed to move water longer distances or pump water from deep wells within an aquifer [36].

\subsection{Treating and Recycling the Sewage a New Hypothesis to Sustain Water Resources}

As already stated, the old belief or hypothesis of using freshwater for all human uses is outdated in the present context of water scarcity since the treated sewage can be recycled for many applications like agriculture, landscape, public parks, golf course irrigation, cooling water for power plants and oil refineries, processing water for mills, plants, toilet flushing, dust control, construction activities, concrete mixing, artificial lakes etc., each country should aim to treat and recycle the sewages of all origins and conserve the freshwater by practicing the new pathway or hypothesis of wastewater treating and cycling.

As already stated, globally about $381.19 \mathrm{~km}^{3}$ of water is used for domestic purposes for the 7736 million people supplying at 135 litre per capita per day as per the World Health Organization (WHO) standard and the sewage generation is $304.95 \mathrm{~km}^{3}$ ( $80 \%$ of water use) and in India about $67.51 \mathrm{~km}^{3}$ of water is used for domestic uses for the 1370 million people in the above year and standard and the sewage generation is $54 \mathrm{~km}^{3}$.

As we are all aware, the treated water in an advanced stage named NEWATER in Singapore is used for drinking, and San Diego, California State, USA is also drinking recycled water because it imports $85 \%$ of its water from Northern California and the Colorado River [15] and therefore, if the present wastewater at $304.95 \mathrm{~km}^{3}$ in 2019 in the world is used for domestic purposes by treating to an advanced stage, it can be supplied for the domestic uses to the 1370 million Indian population in 2019 for 4.5 years and for the world nearly for one year.

If the present wastewater in world is treated to the tertiary level standard and recycled for paddy cultivation in Tamil Nadu state, India we can produce paddy worth of $\$ 81,538$ million per annum at the rate of Rs 53 crore (\$7.5million) per TMC of water (thousand million cubic feet).

Every year so much worth of wastewater, the unpolished blue diamond, is entering the environment and polluting the air, water, land and ecosystems. Hence, a time has come to awaken the public and our leaders of all nations to treat and recycle the sewage and reserve the freshwater for our future generation. This is the need of the hour in the present scenario of water scarcity in many nations.

\section{Conclusions}

Taking the entire 1386million cubic kilometer global water resources as 100litres, the accessible freshwater resources is just half a teaspoon, $0.003 \%$. This fact indicates that there is a limited freshwater resource in the hydrologic cycle.

There was a negligible quantity of freshwater demand 10,000 years ago for agriculture, since our ancestors did not know agriculture. There was no industry prior to the industrial revolution, so no wastewater generation by both these sources. The main use of water at that point of time was only for domestic purposes. Hence, there was a negligible quantity of domestic sewage since the settlements were very small and therefore there was no necessity to treat and recycle the sewage. So, the freshwater in the hydrologic cycle was not decreased due to wastewater and hence the air, water, land and environment were clean.

The water used for agriculture started to be polluted only after the commencement of green revolution in 1940s due to the use of inorganic fertilizer and pesticides to generate more grain with less water and land resources to cope with the population. After the industrial revolution began in $1750 \mathrm{~s}$, the industries let out chemically polluted water. Since synthetic materials like soap, tooth paste and different types of domestic cleaners increased in the household uses, the domestic sewage is also highly polluted. Hence, a huge quantity of polluted water has been generating by the above three sources now. Since this is the scenario everywhere in the world the land, soil, water, air and the environment have been degrading now, only due to human intervention. So, humans are the enemies of the freshwater resource and hence the ecosystem income is slowly decreasing in all ecosystems.

Due to the sewage pollution, the water bodies are either sick, dying and already dead. As per World Water Council 1.1 billion people lack access to safe drinking water, 2.6 billion people lack adequate sanitation and 1.8 million people die every year from diarrhoeal diseases, including $90 \%$ of children under 5 because of drinking contaminated water. This is the pathetic unbearable situation prevailing in the developing and the underdeveloped nations, all due to human 
intervention. We must all understand the basic truth, that sewage entered the earth only after our ancestors, the Homo sapiens, modern human beings as a species, in contrast to other species of ape entered about 200,000 years ago on earth. Prior to this there was no water in the hydrologic cycle in the name of sewage or wastewater.

The main reason for the above situation is pollution of freshwater. Unless the sewage of all origins is treated and recycled for appropriate standard, we cannot arrest the pollution of the earth's natural resources and arrest the prevailing water scarcity in many nations. Therefore, to lead a healthy life with pure air, water, land in a hygienic environment, every nation should commence treating and recycling the sewage to the acceptable tertiary level standard. This is the way to save and reserve the freshwater resource in the hydrologic cycle for our future generation and unless we commence this process now, the entire freshwater resource on the earth including the seawater would be polluted earlier than we expect. Only to create this awareness among the public and nations I wrote this research paper "Rejuvenate Yamuna River by Wastewater Treatment and Management".

So, to conserve and reserve the freshwater resources in the hydrologic cycle for our future generation, each nation should think of a new hypothesis of treating and recycling the sewages of all origins to the tertiary level standard for nondomestic uses or even to an advanced stage, the NEWater for drinking as in Singapore. In the present scenario of water stress and scarcity in the 21st century in many nations, mainly due to the pollution of freshwater, using freshwater for all uses even for toilet is the outdated hypothesis.

Unfortunately, the pollution scenario has been a common scenario in the holey Yamuna also, and hence it is now considered one of the most polluted rivers of the world especially around the Delhi, because of the large amount of wastewater discharge and dumping of garbage. According to a Central Pollution Control Board (CPCB) survey, Delhi contributes $23 \%$ of the total wastewater generated by Class I cities (cities with more than 100,000 people). More shockingly, this is $47 \%$ of the waste generated by 101 Class I cities and 122 Class II cities (Population: 50,000-99,999) in the Ganga basin. The untreated domestic wastewater is dumped in the Yamuna, which has ammonia in it, increases its concentration. The water becomes untreatable when the ammonia concentration reaches to $0.4 \mathrm{mg} / \mathrm{L}$ or more. In Delhi often ammonia in Yamuna River has been found more than $0.4 \mathrm{mg} / \mathrm{L}$ especially during summer. The river has turned grossly polluted due to continuous discharge of domestic wastewater from Palla to Etawah. A healthy river should have minimum $5 \mathrm{mg} / \mathrm{L}$ of DO which is essential for the existence of aquatic life and about $3 \mathrm{mg} / \mathrm{L}$ of BOD. But the above levels are not within the limit in many reaches of Yamuna River. When the Dissolved Oxygen (DO) is less than $3 \mathrm{mg} / \mathrm{L}$, even the robust fishes die. Since DO levels are critical to fish, due to high pollution load, mass death of fishes is reported every year in the polluted reaches of this river. Dissolved Oxygen has fallen from an already low of
0.3 to $0.0 \mathrm{mg} / \mathrm{L}$ between 1996 and 2010 in the Delhi segment. Biochemical oxygen demand (BOD) load has increased from $25 \mathrm{mg} / \mathrm{L}$ to $34.5 \mathrm{mg} / \mathrm{L}$ in 2008 in the same area whereas the acceptable levels is less than or equal to $5 \mathrm{mg} / \mathrm{L}$.

The above pollution scenario of Yamuna River is continuing even today, even after the completion of two Yamuna Action Plans (YAP), I in the1993, and later II in the year 2004. Now under Phase-III, Rs $1,656 / \$$ crore is to be spent for Yamuna restoration. Due to partial/un-treatment sewage through conventional approaches it has not been possible to bring the treated water quality to the acceptable level. Hence, now the author suggests treating and recycling the entire sewage of the Yamuna River basin by a tertiary level standard of treatment and recycling the treated sewage for appropriate nondomestic uses. By practicing this approach, all the polluted waterways in the world including the Yamuna river would be permanently rejuvenated as living rivers.

\section{Recommendations}

Each citizen of the world knows, precipitation is seasonal, and monsoon based, but wastewater generation is perennial happening every second in the world. Since a technology is available in the $21^{\text {st }}$ century to treat and recycle the sewage to the standard of drinking, this resource must be treated to an appropriate standard and recycled.

As we all aware wastewater is generated by different sources (domestic, industry, hospital etc.), and it is natural that each source will have different types of biological and chemical impurities, and hence each source need be treated to an appropriate standard and allowed in a common treatment plan so that to get the toxin free treated water at the end.

Even in a single house settlement, the sewage in septic tanks must be brought to the treatment plant and treated and recycled. Even a single drop of untreated sewage should not be allowed into the environment.

As for India is concerned, it is the nation where 600 million people, more than $50 \%$ of the Indian population open defecate, whereas in Bangladesh only 5\% defecate in the open $[37,38]$. Hence, open defecation is the topmost reason along with sewage for the pollution of water, land and environment in India. So, the unhygienic condition prevails in many areas including in metropolitan city slums. Water stress is another reason for drinking contaminated water and being affected by many diseases in India. So, India now needs to treat and recycle the sewage as well arrest open defecation to lead hygienic life everywhere in the entire nation.

As per the WHO, improved sanitation in developing countries typically yields about USD \$9 worth of economic benefit for every USD \$1 spent, it is an impressive economic income. The benefits include saving time, reducing direct and indirect health costs, increasing the return on investments in education, and safeguarding water resources including in sea. The first element, saving time, should not be underestimated in its contribution to economic benefits in the developing 
world. People without toilets at home spend a huge time each day queuing for public toilets or looking for secluded places to defecate. The World Health Organization estimates this time has an economic value of well over USD 100 billion each year. Moreover, girls' attendance in schools accelerates when it improves its sanitation system. Therefore, addressing sanitation does not only bring about valuable health benefits, it frees up individuals' time so they can do more productive things, like earning income to their family and the nation as well, than searching for a quiet spot to relieve themselves [39]. Hence, India must treat and recycle the sewage and arrest open defecation to protect the water resources and the environment.

By implementing the suggestions and recommendations of this paper, it is possible to save a huge quantity of freshwater, production of biogas, bio-solids and energy and above all, the entire environment, not only the Yamuna River basin but all the 286 transboundary river basins, as well as the national, regional river basins, ecosystems will be kept clean without foul smell and stinking.

This is the way to arrest the present environmental pollution in the entire Earth caused due to untreated sewage and open defecation and thereby to attain water, food, energy, hygiene and environmental securities globally, to each citizen.

To conserve and reserve the freshwater resources in the hydrologic cycle for our future generation, each nation should think of a new hypothesis of treating and recycling the sewages of all origins to the tertiary level standard for nondomestic uses or even to an advanced stage, the NEWater for drinking as in Singapore. In the present scenario of water stress and scarcity in the 21 st century in many nations, mainly due to the pollution of freshwater, using freshwater for all uses even for toilet is the outdated hypothesis.

\section{Acknowledgements}

I would like to thank Thiru U. R. Sankar, Senior Developer, Automatic Data Processing, USA and Mrs. P. M. N Abirami, Senior Engineer, Magellan Navigation, USA and Thiru P. M. N. Ambalavanan, Senior Manager, Bank of America, India for typing, maps preparation and other supports to successfully prepare this research paper.

\section{References}

[1] Mary Anna Evans, (September 17, 2015). Flushing the Toilet Has Never Been Riskier. Some of today's sewers were built before bathrooms as we know them existed. It's time to upgrade.

[2] https://www.americanrivers.org/threats-solutions/cleanwater/sewage-pollution/.

[3] How the Clean Water Act protects your rivers? https://www.americanrivers.org/rivers/discover-yourriver/the-importance-of-the-cwa-to-protecting-your-riversclean-water/.
[4] Ian James, The Desert Sun, (December 10, 2018). This river is too toxic to touch, and people live right next to it.

[5] Karen G Blaettler, November 28, 2018). The Effects of Sewage on Aquatic Ecosystems.

[6] Sucheta Pradhan, (Feb 23, 2018). World's Top 10 Most Polluted Rivers: The Names Will Scare You.

[7] Christian alexander, (April 12, 2019). Cape Town's 'Day Zero' Water Crisis, One Year Later

[8] Toshio Satoa, Manzoor Qadir, Sadahiro Yamamotoe, Tsuneyoshi Endoe, Ahmad Zahoor, (7 August 2013). Global, regional, and country level need for data on wastewater generation, treatment, and use. Agricultural Water Management Journal.

[9] Sophie Hardach, (12 November 2015). How the river Thames was brought back from dead.

[10] Deepshikha Sharma and Arun Kansal. Current condition of the Yamuna River - an overview of flow, pollution load and human use, TERI University.

[11] Raveendra Kumar Rai, Alka Upadhyay, Shekhar P. Ojha C and Vijay P. Singh (2012). The Yamuna River Basin Water Resources and Environment, Water Science and technology Library.

[12] Rai R. K. Dr, Alka Upadhyay Dr, Trived R. C. Dr (2010). Integrated Water Resources Management and Water Quality Modelling of Yamuna River Basin, Baseline of Yamuna River basin.

[13] British Columbia Used Oil Management Association. https://www.rcbc.ca/files/u3/ps_bcuomabrochure.pdf.

[14] Saida, Lebanon. Effects of Dumping Sewage Water Directly into the Sea. http://gobiidae.com/PN/dumpingsewage.html.

[15] UNESCO 2017. The United Nations World Water Development Report 2017. WASTEWATER THE UNTAPPED RESOURCE.

[16] De Groot, R. S., Stuip, M. A. M., Finlayson, C. M. and Davidson, N. (2006). Valuing Wetlands: Guidance for Valuing the Benefits Derived from Wetland Ecosystem Services. Ramsar Technical Report No. 3/ CBD Technical Series No. 27. Gland, Switzerland, Ramsar Convention Secretariat and Montreal, PQ, Secretariat of the Convention on Biological Diversity. www.cbd.int/doc/publications/cbd-ts-27.pdf.

[17] Sonia Madaan. Earth Eclipse. com What is Biodiversity? https://www.eartheclipse.com/ecosystem/why-is-biodiversityimportant-and-reasons-for-loss-of-biodiversity.html.

[18] Corcoran, E., Nellemann, C., Baker, E., Bos, R., Osborn, D. and Savelli, H. (eds) (2010). Sick Water? The central role of wastewater management in sustainable development. A Rapid Response Assessment. Nairobi/Arendal, Kenya/Norway, United Nations Environment Programme (UNEP)/United Nations Human Settlements Programme (UN-Habitat)/GRIDArenda.

[19] Umar Farooq, (February 20, 2018). Environmental Factors Affect Business.

[20] European Environment Agency Technical report-EEA (2010). Ecosystem accounting and the cost of biodiversity losses. The case of coastal Mediterranean wetlands. 
[21] Robert Costanza, Rudolfde Groot, PaulSutton, Sandervan der Ploeg, Sharolyn J. Anderson, Ida Kubiszewski, Stephen Farber, and Kerry Turner R, (2014). Changes in the global value of ecosystem services. Global Environmental Change Volume 26, May 2014, Pages 152-158.

[22] Naomi Stewart (UNU-INWEH) Editor and coordinator (2015) The Value of Land. THE ECONOMICS OF LAND DEGRADATION. initiative.org/fileadmin/pdf/ELD-mainreport_05_web_72dpi.pdf.

[23] Sandeep Sharma K and Mamta Sharma Chhabra (2015). Understanding the Chemical Metamorphosis of Yamuna River due to Pollution load and Human use.

[24] Chetan Chauhan (2015). Yamuna a dead river says report, even as focus on Clean Ganga, Hindustan Times, New Delhi, April 18.

[25] Kumar Vikram, New Delhi (June 10, 2012). Rs 1,500 crore spent on cleaning Yamuna goes down the drain, polluted stretch increases from $500 \mathrm{~km}$ to $600 \mathrm{~km}$. 22 drains between Wazirabad Barrage and Okhla Barrage discharge untreated sewage into the river.

[26] CPCB, (2000). Status of water quality of river Yamuna and drains adjoining river Yamuna in Delhi. Information submitted to the Hon'ble Supreme Court, of India.

[27] Bureau, GN (July 24, 2017). Rs 1,514 crore already spent on cleaning Yamuna. Under Phase-III, Rs 1,656 crore to be spent.

[28] http://blogs.ei.columbia.edu/2011.

[29] Guardian Newspapers Limited, 2014, The Hindu, 11.8.2014.

[30] Metcalf and Eddy (2013). Wastewater Engineering: Treatment and Resource Recovery.

[31] Dr. P. M. Natarajan, Dr. N. Vasudevan, Shambhu Kallolikar, Dr. G. Rangaraju (2015). 'Clean Chennai is a Utopia, Without
Restoration of Waterways'. Paper presented in the ASIAPACIFIC Wastewater Treatment and Reuse Conference 2015 28 June - 1 July 2015 Stephen Riady Centre, UTown, National University of Singapore, Singapore.

[32] Dr. P. M. Natarajan, Shambhu Kallolikar and S. Ganesh (2016). Transforming Ganges to be a Living River is a Pipe Dream Without Wastewater Management. World Academy of Science, Engineering and Technology International Journal of Environmental, Chemical, Ecological, Geological and Geophysical Engineering Vol: 10, No: 2, 2016.

[33] Department for Environment, Food and Rural Affairs, London, (2012). Wastewater treatment in the United Kingdom-2012. Implementation of the European Union Urban Wastewater Treatment Directive-91/271/EEC.

[34] Neetu Chandra Sharma (19 June 2016). River Yamuna 'close to death': New study warns Delhi's waterway is 'toxic' even after treatment and should not be used for drinking or irrigation.

[35] Government of India Ministry of Environment, Forest and Climate Change Lok Sabha unstarred question no. 2541, 28th May 2018.

[36] EPA. Water Reuse and Recycling: Community and Environmental Benefits https://www3.epa.gov/region9/water/recycling/.

[37] Gaurav Tyagi, (May 09, 2017). Is India Really 'Winning Its War' on Open Defecation? The "Clean India" campaign may have good results on paper, but the reality does not match the numbers.

[38] Trishal, (March 22nd, 2018). Beating the bugs: How Bangladesh vanquished Diarrhoea.

[39] WHO, UNICEF, 2017. Progress on drinking water, sanitation and hygiene 2017 update and SDG baseline. 